\title{
Impact of the Elements Affecting the Negative Iron-Based Phases Morphology in Aluminium Alloys - Summary Results
}

Dana Bolibruchová, Marek Brůna

Department of technological engineering, Faculty of Mechanical Engineering, University of Žilina, Univerzitná 1,010 26 Žilina, Slovakia, E-mail: danka.bolibruchova@fstroj.uniza.sk, marek.bruna@fstroj.uniza.sk, Tel.: + 421415132772

The presented article includes a summary of the experimental works regarding the possibility of using and replacing more expensive primary alloys with secondary alloys. Although the use of secondary alloys is relatively widespread today, they are mostly used for the production of lower or medium quality castings, respectively with a low ratio of primary and secondary alloys. Experimental works was aimed at the additional processing of the secondary alloys by suitable methods or their combination, to achieve a secondary alloy with mechanical properties similar to the primary one, thus enabling the use of such an alloy to produce high-quality castings. Correctors used during experimental works are $\mathrm{Cr}, \mathrm{Ni}, \mathrm{V}$ and their combination applied to various aluminium alloys with different chemical composition.

Keywords: Secondary alloy, aluminium, iron-based phase, high-quality castings

\section{Acknowledgement}

This work was created within the framework of the VEGA project grant no. 1/0494/17. The authors thank the grant agency for their support.

\section{References}

[1] EAA, 2016. Activity Report 20215. Unlocking Sustainable Value Chains [online]. [cit.20.4.2016] Dostupné na internete:

[2] http://european-aluminium.eu/media/1592/2015_european_aluminium_activity_report.pdf.

[3] ROUČKA, J. (2004). Metalurgie neželezných kovov. Akademické nakladatelství CERM, 2004, 143s

[4] MACKO, J. (2013). Vplyv vyššieho množstva železa na mechanické vlastnosti a mikroštruktúru sekundárnych zliatin na báze Al-Si-Cu. Doktorandská dizertačná práca, ŽU, 2013

[5] ŽIHALOVÁ, M (2016). Možnosti eliminácie vyššieho množstva železa v zliatine typu EN AC 43000. Doktorandská dizertačná práca, ŽU, 2016

[6] RICHTÁRECH, L. (2016). Možnosti eliminácie nepriaznivého účinku železa v sekundárnej zliatine. AlSi7Mg0,3 Doktorandská dizertačná práca, ŽU, 2016

[7] KHALIFA, W. (2003). Role of inclusions in the precipitation of $\alpha$-aluminium and Fe-intermetallics in aluminium rich corner of the Al-Si-Fe ternary system. 2003. Dissertation thesis.

[8] TAYLOR, J. A. (2004). The effect of iron in Al-Si casting alloys. In $35^{\text {th }}$ Australian Foundry Institute National Conference, Adelaide, South Australia, 2004, pp. 148 - 157.

[9] BOLIBRUCHOVA, D., RICHTARECH, L., MACKO, J. (2014). Possibilities for eliminating a larger amount of iron in the secondary AlSi6Cu4 alloy with chrome, In. Materials and technology. Vol. 48, no. 6 (2014), s. 817821, ISSN 1580-2949.

[10] BOLIBRUCHOVA, D., MACKO, J., BRU゚NA, M. (2014). Elimination of negative effect of Fe in secondary alloys AlSi6Cu4 (EN AC 45 000, A 319) by nickel. In: Archives of metallurgy and materials. Vol. 59, iss. 2 (2014), s. 717-721, ISSN 1733-3490.

[11] ZIHAlOVA, M., BOLIBRUCHOVA, D., CAIS, J. (2015). Microstructural analysis of nickel influence in Alsi10MgMn alloy with increased iron level, In: Manufacturing technology, Vol. 15, no. 4 (2015), s. 743-748, ISSN 1213-2489.

[12] ZIHALOVA, M. BOLIBRUCHOVA, D. (2016). Evaluation of vanadium influence in AlSi10MgMn alloy with increased iron level. In: Manufacturing technology, Vol. 16, no. 2 (2016), s. 471-475, ISSN 1213-2489.

[13] BOLIBRUCHOVA, D., ZIHALOVA, M. (2014). Vanadium influence on iron based intermetallic phases in AlSi6Cu4 alloy. In Archives of metallurgy and materials. 2014, vol. 59, no. 3, p. 1029-1032, ISSN 1733-3490. 
[14] ŠČURY, J., BOLIBRUCHOVÁ, D., ŽIHALOVÁ, M. (2016). Effect of nickel on the properties of the AlSi10MgMn alloy with increased iron content. In: Manufacturing technology, Vol. 16, no. 1 (2016), s. 243-247. ISSN 1213-2489.

[15] Norma STN EN 1706: Hliník a zliatiny hliníka. Odliatky. Chemické zloženie a mechanické vlastnosti, 2010.

[16] BOLIBRUCHOVA, D., ZIHALOVA, M. (2014). Vanadium influence on iron based intermetallic phases in AlSi6Cu4 alloy. In Archives of metallurgy and materials. 2014, vol. 59, no. 3, p. 1029-1032, ISSN 1733-3490.

[17] RICHTÁRECH, L., BOLIBRUCHOVÁ, D. (2014). Effect of selected elements on the microstructure of secondary Al-Si alloys. In: Manufacturing technology, Vol. 14, no. 3 (2014), s. 431-437, ISSN 1213-2489.

[18] BOLIBRUCHOVA, D., RICHTARECH, L., DOBOSZ, S., M., MAJOR-GABRYS, K. (2017). Utilisation of Mould Temperature Change in Eliminating the Al5FeSI Phases in Secondary AlSi7Mg0.3 Alloy. In Archives of Metallurgy and Materials. 2017, vol. 62, no. 1, p. 357-362, ISSN 1733-3490.

[19] KRIVOŠ, E., PASTIRČÁK, R., MADAJ, R. (2014). Effect of technological parameters on the quality and dimensional accuracy of castings manufactured by patternless process technology. In Archives of metallurgy and materials. 2014, vol. 59, no. 3, p. 1069-1072, ISSN 1733-3490.

[20] PASTIRČÁK, R., ŠČURY,J. (2016). Effect of technological parameters on microstructure in alloy AlCu4Ti using squeeze casting. In American Institute of Physics Publising. 2016, AIP conference proceedings, vol. 1745, ISSN 0094-243X.

[21] ZYCH, J., MOCEK, J. (2017). Kinetics of gas emissions from moulding and core sands, gasification patterns and protective coatings - The new investigation method. In: Manufacturing Technology. ISSN 1213-2489, 2017, vol. 17 , iss. 1 , s. 126-13, ISSN 1213-2489. 